\title{
\#20latfotografipwsftvit [1]
}

Zadanie kuratorskie jest zawsze dużym wyzwaniem, zwłaszcza gdy w grę wchodzi próba przedstawienia dorobku nie jednego twórcy czy grupy o mniej lub bardziej sprecyzowanej koncepcji artystycznej, lecz heterogenicznej i sprzyjającej ciągłym poszukiwaniom instytucji, jaką jest Katedra Fotografii Szkoły Filmowej w Łodzi. Dla mnie, z zawodu bardziej filozofki i artystki niż kuratorki, od początku było jasne, że aby sprostać temu zadaniu, trzeba znaleźć jakiś klucz, który pozwoli ogarnąć ten ogrom wielorakich, już to sprzecznych, już to uzupełniających się strategii. Z racji bardzo krótkiego czasu, jakim dysponowałam - niespełna trzy miesiące - już na samym początku odpadł pomysł, by upamiętnić dwudziestolecie Katedry, stosując klasyczny i poniekąd narzucający się klucz historyczny. Potrzeba byłoby na to co najmniej roku przygotowań. Kolejny pomysł, by zaprezentować przede wszystkim prace twórców najbardziej uznanych, wydał mi się z kolei nieco niesprawiedliwy i niewyczerpujący bogactwa kierunków, tendencji i strategii artystycznych Szkoły. Dlatego też postanowiłam, może trochę przewrotnie, spojrzeć na te dwadzieścia lat przez pryzmat katalogowania.

Żyjemy w epoce cyfryzacji, powiększającej się w astronomicznym tempie bazy danych. Wszelkie informacje, także te wizualne, wpuszczone w wirtualną rzeczywistość, w której spędzamy coraz więcej czasu, gromadzą się w coraz pojemniejszych zbiorach i katalogach, pod określonymi tagami. Człowiek ma potrzebę kontroli, która objawia się między innymi w obsesji porządkowania, nazywania i katalogowania, które służą także sprawowaniu pewnej władzy, o czym pisał chociażby Michel Foucault. Ostatnio ze strategii czysto „władczej” działania te zmieniają się jednak coraz bardziej w strategię prostego przetrwania. W przestrzeni permanentnej komunikacji i usieciowienia tagowanie wyznacza sposób radzenia sobie z nadmiarem informacji i bodźców. Strategia ta ma jeszcze jeden ważny aspekt: oparta jest na procesie wzajemnego oddziaływania najróżniejszych kierunków i tendencji. Kumulowanie danych pod wybranym znacznikiem tworzy w sieci punkt osobliwy, z natury swej otwarty na kolejne połączenia $\mathrm{z}$ innymi zbiorami, katalogami czy folderami. Dotyczy to wszelkiego rodzaju danych, w tym także obrazów. Co więcej, los szeroko rozumianych

[1] Tekst opublikowany w albumie \#2olatfotografipwsftvit, wydanym z okazji jubileuszu 65-lecia
PWSFTViT oraz 2o-lecia specjalności fotografia PWSFTViT. 
obrazów, funkcja, jaką pełnią w świecie cyfryzacji i katalogowania, wydają się szczególnie symptomatyczne. Każde działanie artystyczne, wszystkie pomysły, indywidualne czy grupowe poszukiwania, które były czy są prowadzone w Szkole i dotyczą działań na obrazie, mają wpływ na sieć połączeń świata sztuki audiowizualnej. Żaden ze sposobów obrazowania, jakie pojawiły się w trakcie dwudziestoletniej historii Katedry Fotografii PWSFTViT, nie pozostaje więc bez znaczenia, wszystkie wpisują się w coś w rodzaju „neuronowej sieci” powiązań $\mathrm{z}$ innymi kulturowymi tendencjami i zjawiskami obecnymi w świecie.

W efekcie wspólnej - z nieocenionymi Anną Kazimierczak i Anną Zarychtą - pracy nad archiwami szkoły i open callami, a także dzięki przeszukiwaniu blogów, stron internetowych naszych absolwentów i studentów, wyłoniły się pewne kategorie, który potraktowałyśmy jako podstawę kolekcji pokazywanej na tej wystawie. Zebrałyśmy około 30 charakterystycznych „chmur tagowych” - zbiorów prac, które łączyła jakaś szczególna tendencja estetyczna lub znaczeniowa, jak na przykład kategorie „białe”, „raj”, „enumeracje” czy „po pierwsze nośnik”. Lista ta jest oczywiście otwarta i do pewnego stopnia arbitralna - stanowi efekt naszych własnych skojarzeń i poszukiwań. Jestem w stanie wyobrazić sobie całkiem inne sieci połączeń. Co ważne, to nie w "autokratycznym” dookreśleniu miał tkwić sens tego projektu. W obranej tu strategii kuratorskiej chodzi o przekazanie pewnej myśli dotyczącej współczesnej epoki obrazu - w której również szeroko pojęta fotografia nadal pełni bardzo istotną rolę - a mianowicie, że funkcja i rola obrazu w dobie cyfryzacji i Internetu została przesunięta. Oddziałuje on teraz w chmurze tagowej, a moc owego oddziaływania nie tkwi już w indywidualnej „aurze” wybranego kadru, lecz w pewnej kategorii spajającej dany zbiór obrazów, w powieleniu i powtórzeniu, gdzie obrazy - parafrazując słowa W.J.T. Mitchella - wywołują swoiste tarcie, pewien dyskomfort, zmuszają nas do przemyślenia na nowo naszego miejsca w ikonosferze.

\section{Aleksandra Hirszfeld kuratorka wystawy \#2olatfotografiipwsftvit}

e-wystawa[2]:

2olatfotografiipwsftvit.pl

[2] Wystawa - dostępna także w sieci - dość przewrotnie próbuje zmierzyć się z wyzwaniem zobrazowania dwóch dekad fotografii w Szkole Filmowej. Fotografii, która - gdzieś w tle dominującego w Szkole obrazu filmowego - wypracowała swoje strategie i przestrzenie istnienia raz sięgając np. po historyczny kolodion, innym razem pytając o granice medium, korzystając z technik wideo, a w przysłowiowej przestrzeni „pomiędzy” odnajdziemy m.in. szeroko rozumianą i płynnie przenikającą się fotografię konceptualną, dokument, reportaż, a także prace umiejętnie balansujące między sztuką a reklamą. $\mathrm{Na}$ wystawie zaprezentowanych zostało ponad 250 prac studentów i absolwentów fotografii PWSFTViT. 
Prezentowane obok fotografie pochodzą z publikacji:

\#2olatfotografipwsftvit

oraz z wystawy w Miejskiej Galerii Sztuki w Łodzi (Ośrodek Propagandy Sztuki).

s. 224 Jakub Kamiński, Salary Man, 2009

s. 225 Bogdan Krężel, Czakram wawelski/The Wawel Chakra, 2001

s. 226 Natalia Szczęch, Percepcja/Perception, 2011 (trzy pierwsze od góry)

Piotr Cielecki, Kiss, 2011

s. 227 Ewa Ciechanowska\&Urbański Artur, Into the wild, 2012

Agata Opalińska, bez tytułu/untitled, 2012

s. 228 Dominik Tarabański, Transitions, 2012

s. 229 Przemek Dzienis, NN Personality - Monika, 2010

Wojciech Skrzypczyński, SWAY, 2013

s. 230-231 Krzysztof Panek, Ewpatori, 2006

s. 232 Katarzyna Krakowiak, Strumień zmian/The flow of changes, 2011-2012

Urszula Tarasiewicz, z cyklu: Nowe legendy miejskiel from series: The new urban legends, 2010

Monika Kokoszyńska, bez tytułu/untitled, 2012

Sonia Szóstak, Kornelia, 2012

Tomasz Pastyrczyk, bez tytułu/untitled, 2010

Karol Piechocki, Portret jako narzędzie wyrazu/Portrait as a means of expression, 2009

s. 233 Maria Cieślak, bez tytułu/untitled, 2013

Anna Orłowska, Przeciek/Leakage, 2011

Bogdan Krężel, Stanisław Lem, 2000 
224 \#2OLATFOTOGRAFIIPWSFTVIT
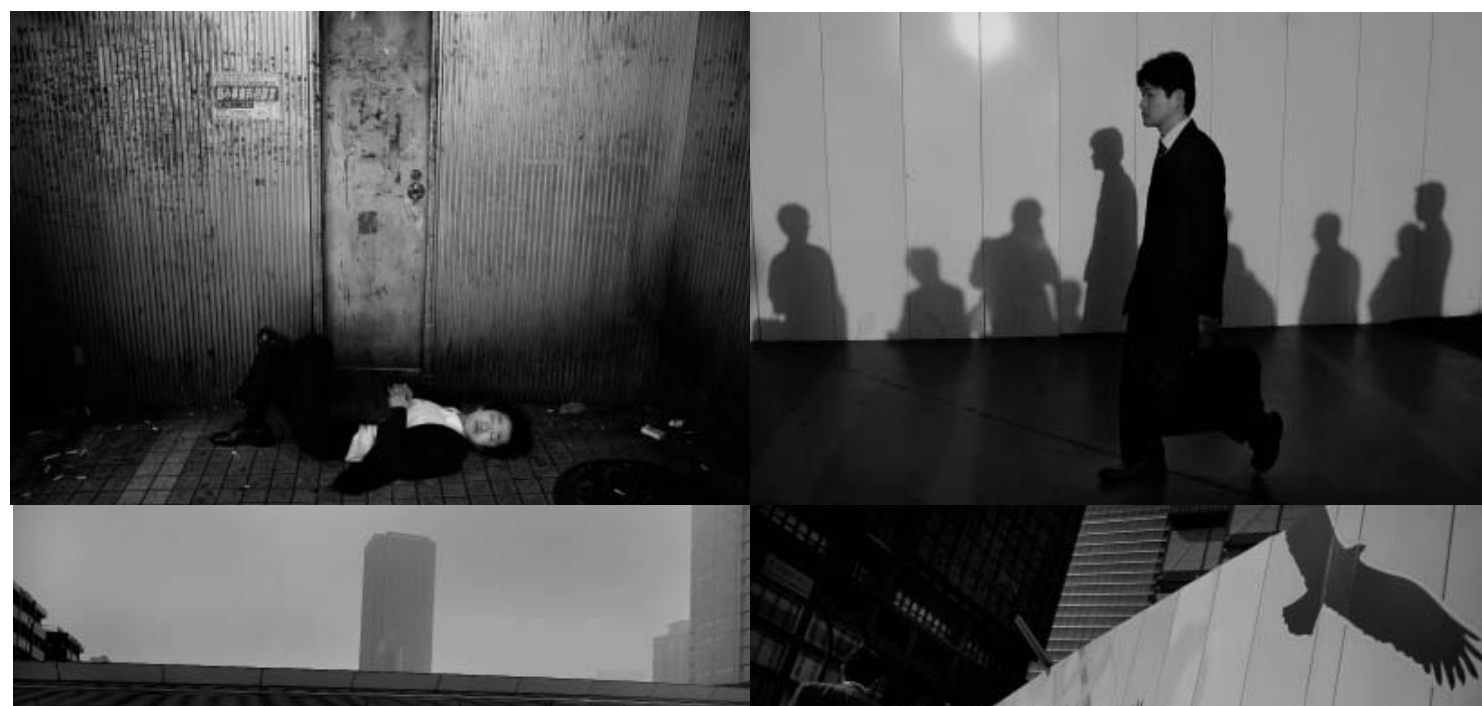

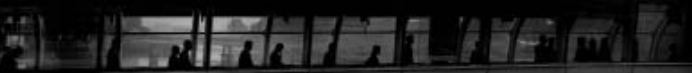

$\circ$
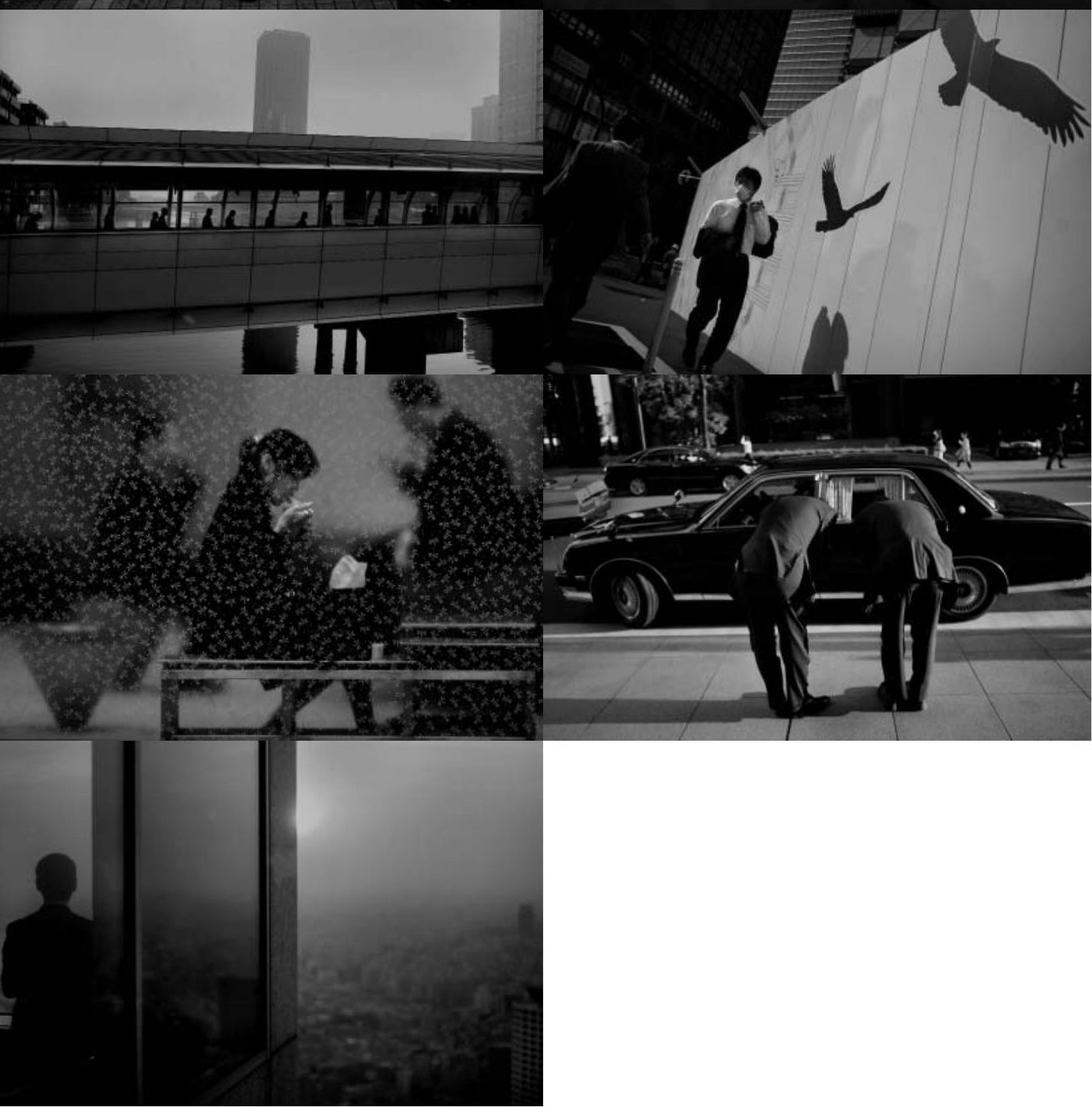


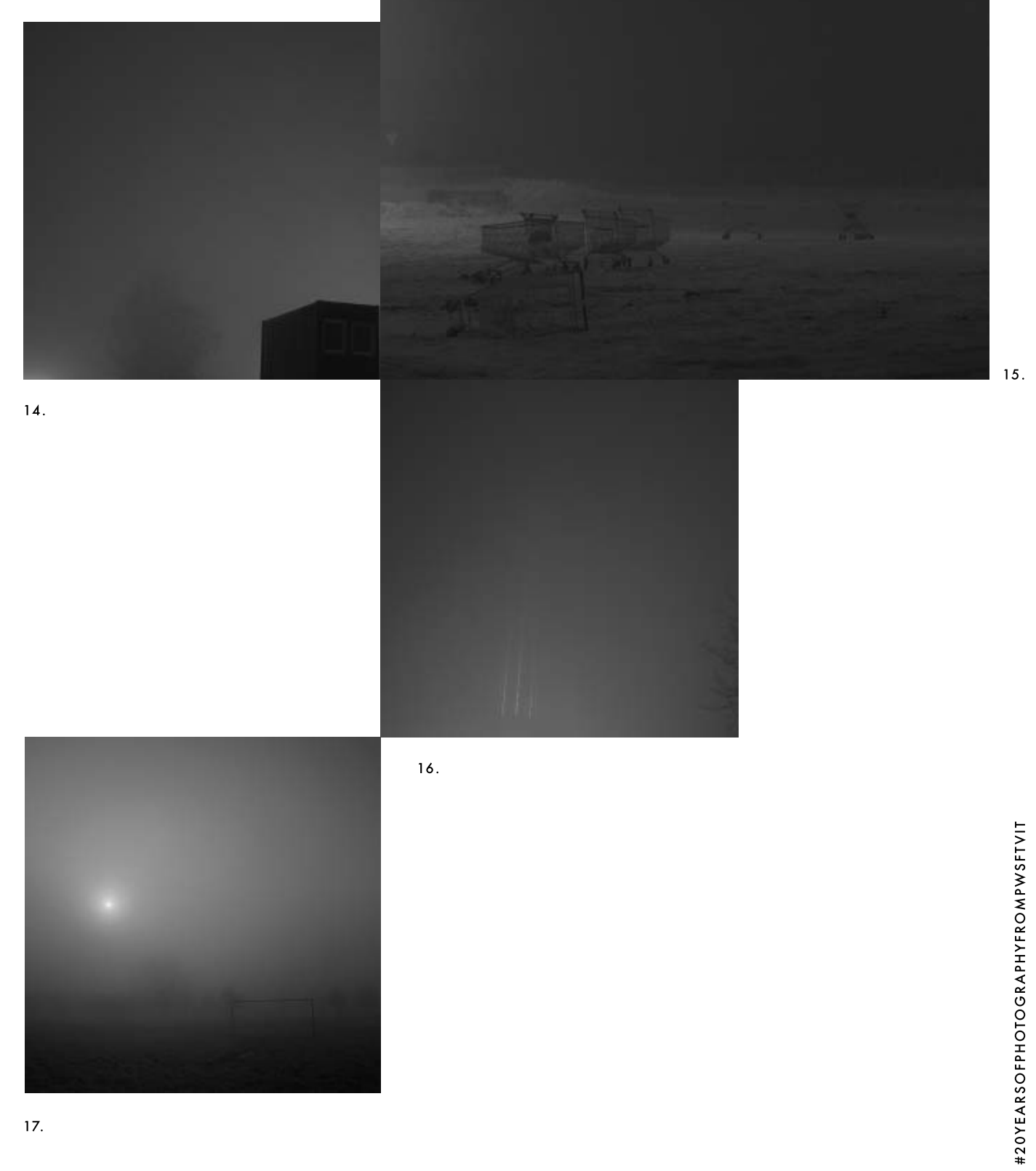




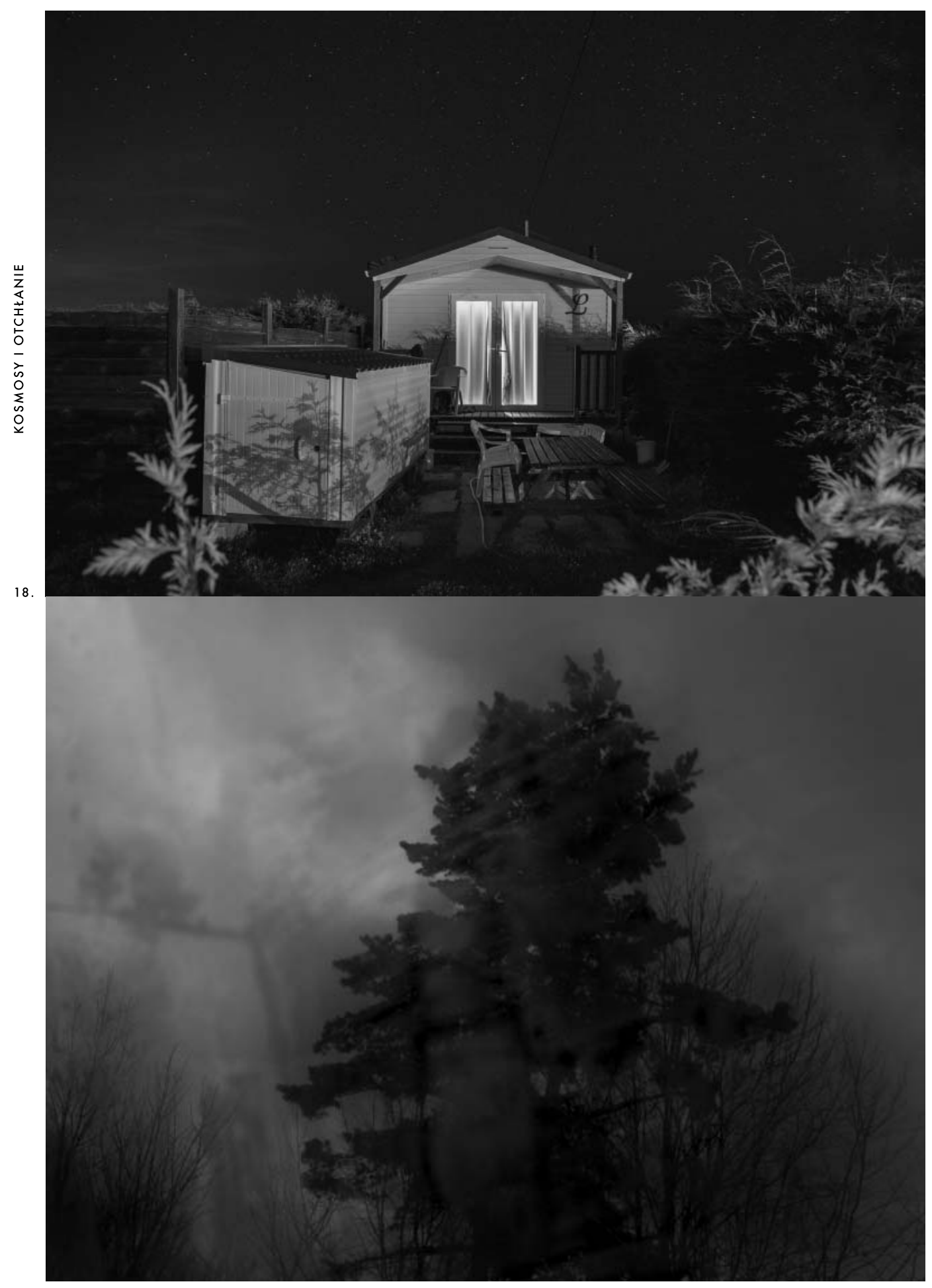


22.

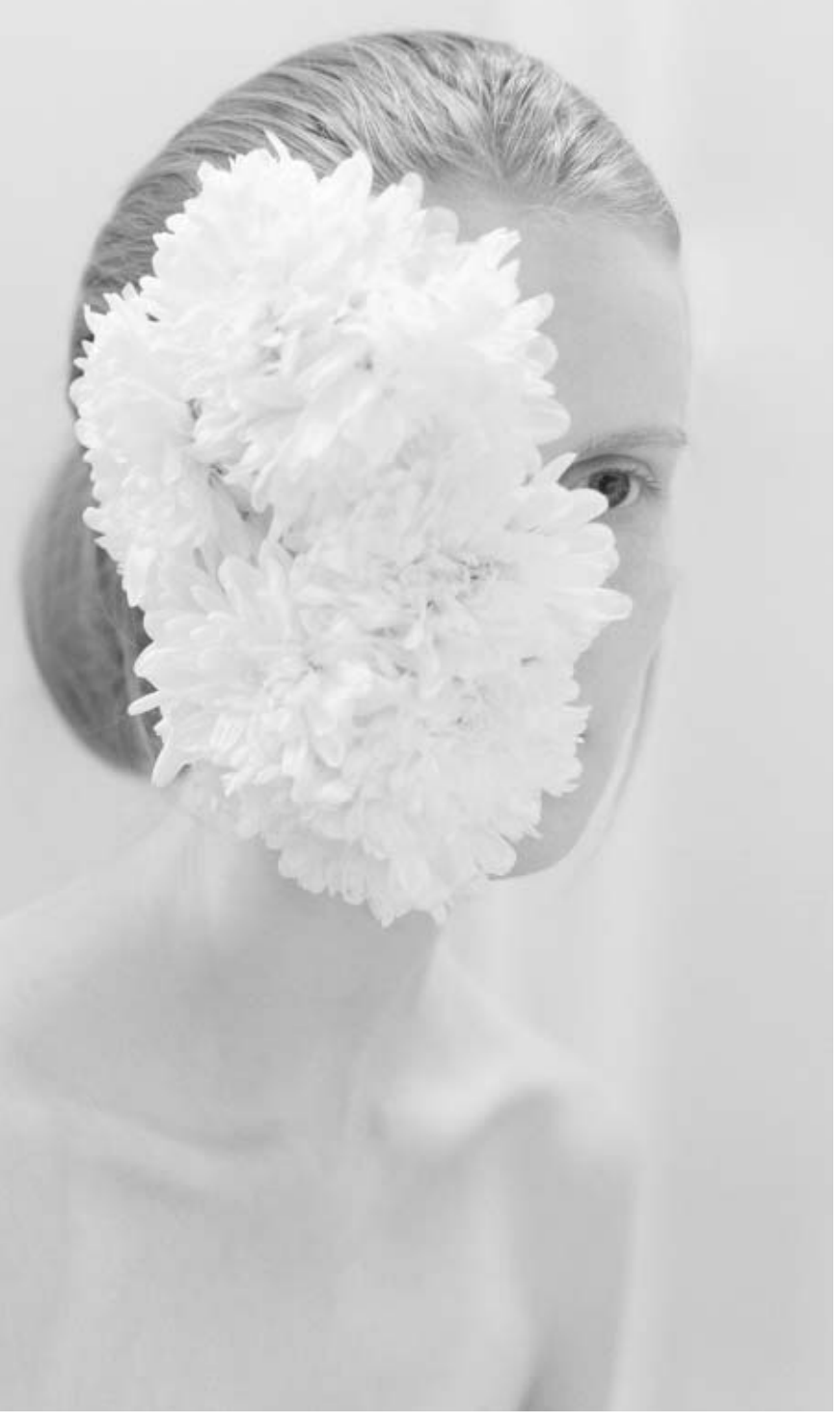




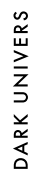

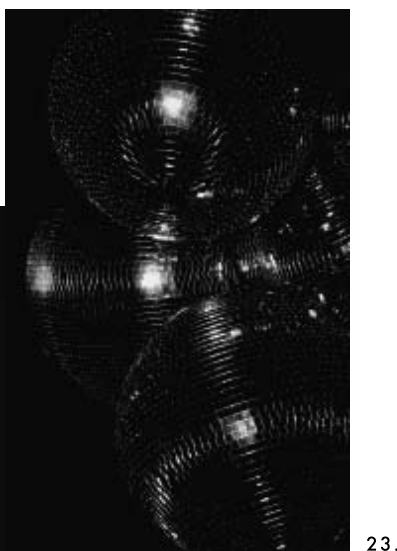

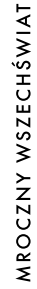




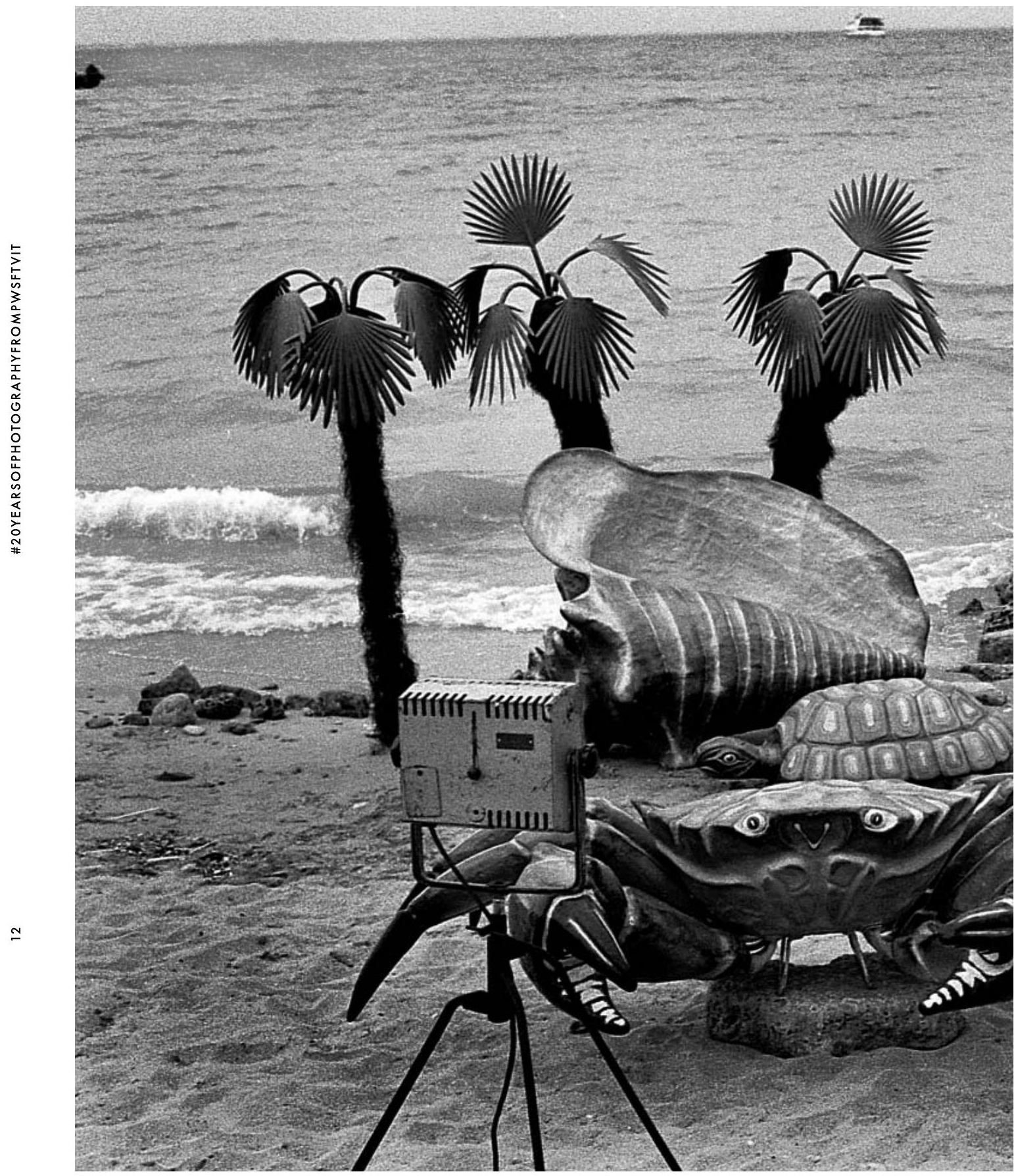




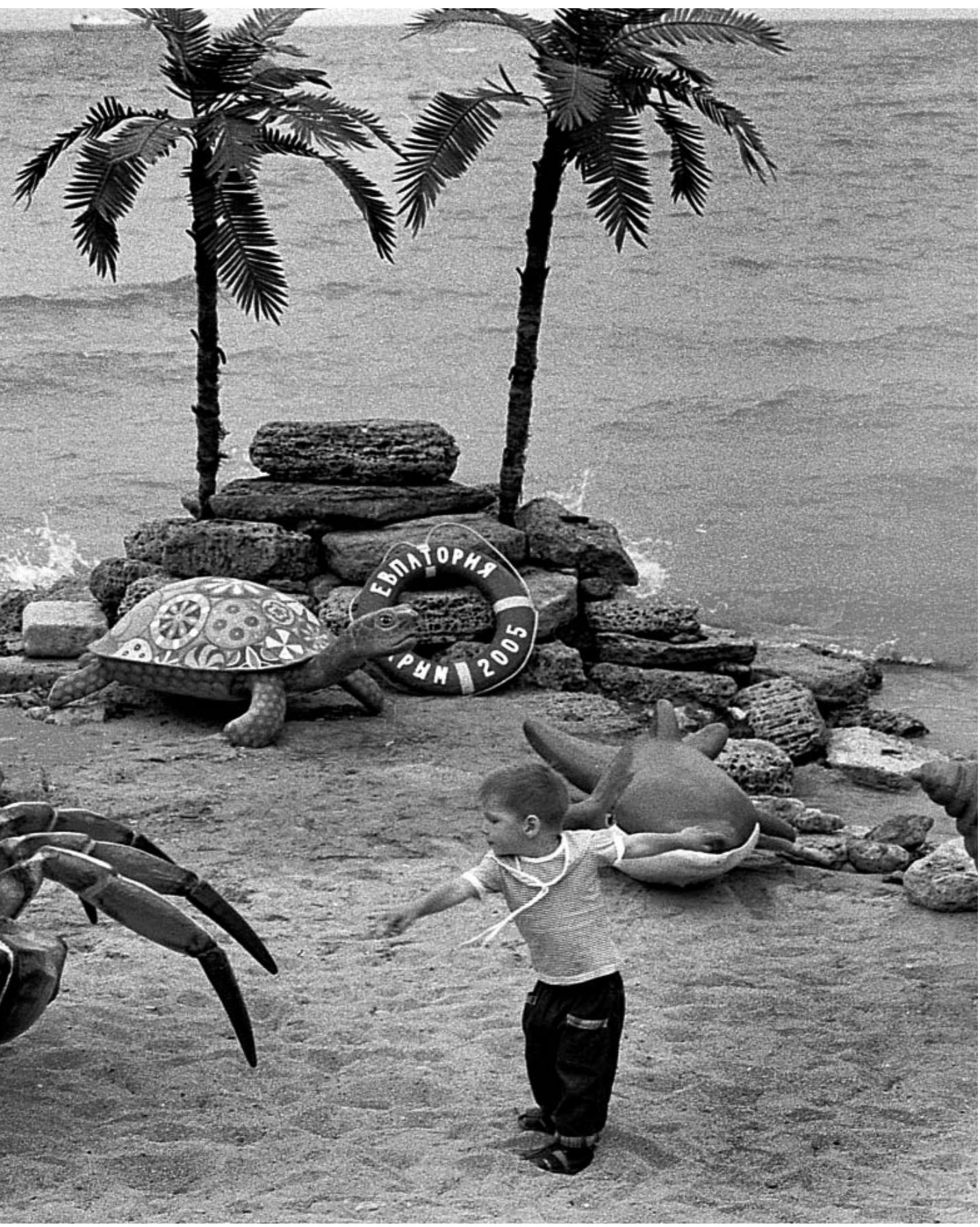




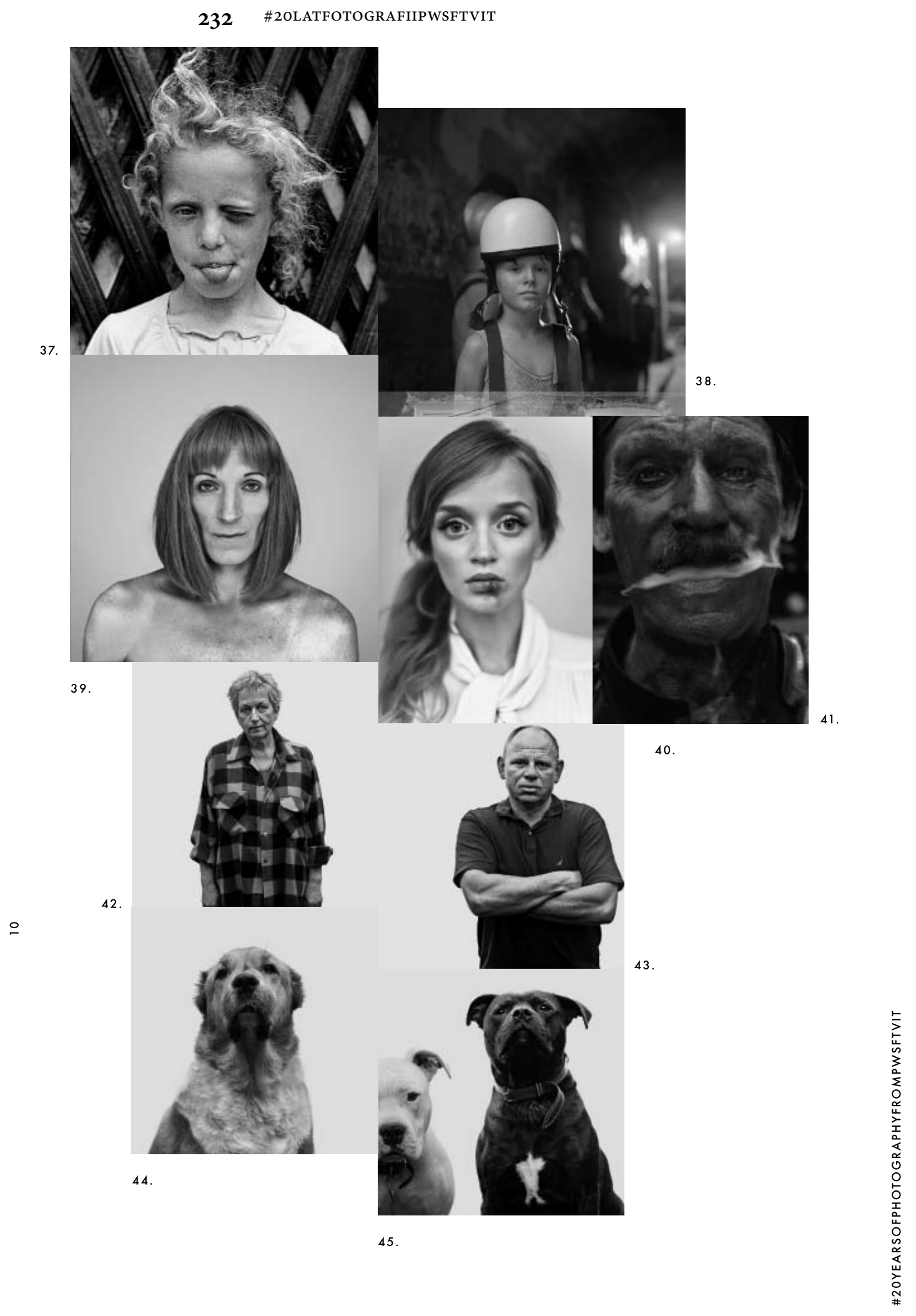




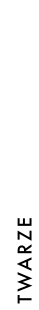

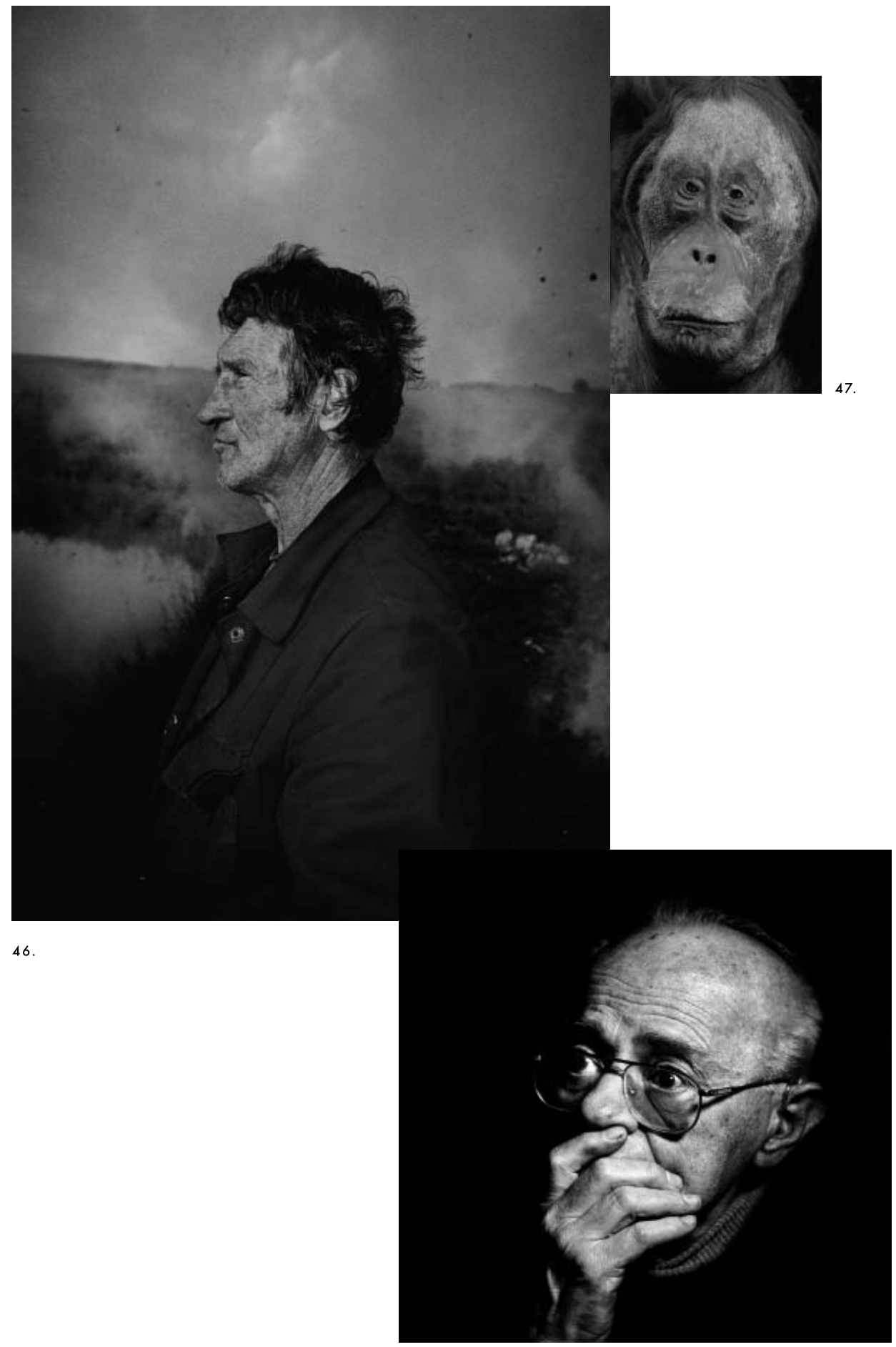


KRZYSZTOF PIJARSKI

\section{Fotografia \\ w nieprzezroczystym świecie[ $\left.{ }_{1}\right]$}

Istotą rzeczywistości jest sens. Co nie ma sensu, nie jest dla nas rzeczywiste. Każdy fragment rzeczywistości żyje dzięki temu, że ma udział w jakimś sensie uniwersalnym.

Bruno Schulz, Mityzacja rzeczywistości[2]

Wystawa i publikacja \#2olatfotografipwsftvit objawiają nam się w osobliwym momencie. $Z$ jednej strony są niewczesne, w końcu dwudziestą rocznicę istnienia studiów fotograficznych w Szkole Filmowej obchodziliśmy w ubiegłym roku. Mogłoby to sugerować, że długo się do tej wystawy i książki szykowaliśmy, rekonstruując perypetie fotografii jako kierunku studiów pnącego się ku ciągle jeszcze nieosiągalnej samodzielności (fotografia pozostaje katedrą podporządkowaną wydziałowi operatorskiemu, co - rzecz jasna - niekoniecznie jest rzeczą niepożądaną). Z drugiej jednak strony czasy kryzysu nie są najlepszym momentem upamiętniania przeszłości, powoływania się na dawną czy też niedawną wielkość. Czasy kryzysu wymagają raczej namysłu, próby określenia miejsca, w którym się znaleźliśmy, oraz kierunku, w którym chcielibyśmy podążać.

Mówiąc o kryzysie, nie miałem jednak na myśli przede wszystkim kryzysu finansowego, którego skutki wszyscy odczuwamy zwłaszcza zaś studenci, którzy po ukończeniu szkoły będą musieli znaleźć sobie miejsce w tej (być może w zbyt niewielkim stopniu!) zmienionej i zawodowo o wiele trudniejszej rzeczywistości. Myślałem tu głównie o przemianach w samym polu fotografii, które być może jesteśmy w stanie ujrzeć w całej ich rozległości dopiero teraz. Ubiegłoroczne zamknięcie w Polsce ostatnich redakcji fotograficznych w dziennikach o zasięgu krajowym było wyraźnym znakiem końca pewnej epoki - epoki (humanistycznego) fotoreportażu, w formie, w jakiej się narodził podczas wojny domowej w Hiszpanii i w której osiągnął największy rozkwit za czasów ilustrowanych tygodników, takich jak „Life” czy polski „Świat”[3]. Jeśli chcemy, aby fotografia nadal opowiadała o współczesnym świecie, wydobywała jego pęknięcia, momenty spełnienia i ukryte oblicza, trzeba będzie znaleźć alternatywne sposoby

[1] Tekst opublikowany w albumie \#2olatfotografipwsftvit, wydanym z okazji jubileuszu 65-lecia PWSFTViT oraz 2o-lecia specjalności fotografia PWSFTViT.

[2] B. Schulz, Mityzacja rzeczywistości, w: idem, Republika marzeń. Utwory rozproszone. Opowiadania.
Fragmenty. Eseje. Rysunki, wybór, oprac. i posłowie J. Ficowski, Chimera, Warszawa 1993, s. 49. [3] Oczywiście, przemiany te były widoczne wcześniej, ostatnie wydarzenia jednak dobitnie podkreśliły ich nieodwracalność. 
funkcjonowania, zdobywania funduszy na realizację projektów, nowych form dystrybucji. Tu właśnie ujawnia się najgłębszy kryzys, a raczej moment przełomu[4]. Dlatego też wystawa i książka koncentruje się na młodszym pokoleniu artystów związanych ze szkołą, ponieważ to oni naprawdę przeżywają ten moment.

Wiele już powiedziano na temat wpływu, jaki cyfryzacja wywarła zarówno na produkcję, jak i recepcję obrazów fotograficznych. Na zmagania studentów Szkoły Filmowej z tym problemem wskazali już kilka lat temu Ewa Ciechanowska i Dawid Furkot, stwierdzając, że

[n] owy sposób wytwarzania obrazu, jaki zaistniał dzięki fotografii cyfrowej, wpłynął znacząco na nasze postrzeganie fotografii i nie mamy tutaj do czynienia z chwilowym zakłóceniem, ale trwałą przemianą doświadczenia odbioru i tym samym koniecznością wypracowania nowych nawyków w obcowaniu z obrazami fotograficznymi[5].

Z dzisiejszej perspektywy wydaje się jednak, że cyfryzacja dokonała największych zmian nie tyle w dziedzinie wytwarzania obrazu fotograficznego (choć i to prawda), ile przede wszystkim jego upowszechniania, jego cyrkulacji. Poprzez wybór formy i struktury niniejszej publikacji - a także wystawy, której towarzyszy - jej twórcy próbują zdać sprawę z tego przewrotu. Na ten temat szerzej wypowiada się powyżej kuratorka wystawy Aleksandra Hirszfeld.

Współczesne media społecznościowe dokonały radykalnego spłaszczenia pola kultury fotograficznej: tradycyjne hierarchie i kanały selekcji wprawdzie nadal istnieją, lecz równolegle powstała rozległa sieć relacji horyzontalnych, łączących ludzi niekiedy bardzo od siebie odległych, ale bliskich sobie pod względem wrażliwości, postawy, praktyki. W tej sytuacji czasem dochodzi do niespodziewanych spotkań, spięć i wspólnych przedsięwzięć, które mimo marginalnego statusu zdobywają duży rozgłos i uznanie[6]. Jako przykład takiej dynamiki można podać „TIFF. Trochę Inny Festiwal Fotografii”, powołany do życia w roku 2011 przez Macieja Bujko i Franciszka Ammera, dwóch studentów szkoły, którzy właśnie opuszczają jej mury. Mimo młodego wieku - i w związku z tym nieznaczącej jeszcze pozycji w świecie współczesnej fotografii - udało się im stworzyć ciekawą imprezę, w której wzięli już udział twórcy o międzynarodowej pozycji.

[4] Znamiona swoistego momentu przełomowego nosi też fakt, że Szkoła Filmowa wygasza swój program studiów zaocznych, program, który wydał kilka pokoleń znakomitych artystów i zawodowców $\mathrm{w}$ dziedzinie fotografii. Choć trudno w tym momencie orzec, jaki to będzie miało wpływ na środowisko artystyczno-intelektualne Szkoły, powinno na pewno zmotywować nas do zastanowienia się na tym, dokąd chcemy zmierzać jako uczelnia.

[5] E. Ciechanowska, D. Furkot, [wprowadzenie kuratorskie], w: Disconnected Images / Rozłączone obrazy, red. E. Ciechanowska, D. Furkot, PWSFTViT, Łódź 2011, s. 4.

[6] Ów efekt swoistej kontrsfery społecznej widzialności obserwowaliśmy gdzie indziej na przykładzie Arabskiej Wiosny, gdzie duża część zapisu i komentarzy tych wydarzeń została wyprodukowana przez samych uczestników, nie zaś oficjalne media, które same na nie się powoływały. Tym sposobem serwisy YouTube i Twitter, a także Facebook, stały się kanałami wprowadzania w obieg nowych informacji. 
Ten nowy, usieciowiony świat rozwija się dynamicznie. Wciąż pojawiają się nowe technologie prezentacji i upowszechniania fotografii, do tego stopnia, że bardzo trudno za tym rozwojem nadążać[7]. Jak więc uczyć posługiwania się tymi technologiami, skoro zmieniają się one $\mathrm{z}$ taką prędkością? Jak za tym rozwojem nadążyć?

To samo dotyczy źródeł zdobywania i produkcji wiedzy. Dziś nie biblioteka, lecz Internet jest podstawowym punktem odniesienia dla młodego pokolenia fotografów (i nie tylko). Trudno jednak traktować tę sytuację jako zjawisko wyłącznie pozytywne. Problemem jest bowiem nie dostępność - liczba książek i materiałów dostępnych online jest przecież nieprzebrana - lecz umiejętność odsiania plew od ziarna, formułowania trafnych pytań, nazywania problemów.

Stwierdzenie, że świat stracił na przejrzystości (a więc hierarchii), że współistnieje w nim wiele konkurujących ze sobą dyskursów, pozycji i praktyk, że niezmiernie trudno wypowiadać w nim kategoryczne sądy, choć nierzadko jest to konieczne - to wszystko nie wydaje się bardzo odkrywcze. Jednocześnie opisywane powyżej zjawiska i przemiany stanowią poważne wyzwanie dla szkoły. Zmuszają do zastanowienia się nad tym, czego i w jaki sposób uczyć. I to jest największe wyzwanie, przed którym stoimy jako pedagodzy łódzkiej Szkoły Filmowej.

Jak nauczyć młodych adeptów fotografii orientacji w tym coraz bardziej złożonym świecie, jak im pomóc wypracować narzędzia krytyczne, własny, odpowiedzialny sposób widzenia tych procesów i przemian? Jak pomóc $\mathrm{w}$ formułowaniu wizualnych odpowiedzi na tę rzeczywistość? W myśleniu za pomocą obrazów, a nie tylko ilustrowaniu czy rejestrowaniu świata takim, jakim się zdaje. Nie ma, rzecz jasna, prostej odpowiedzi na to pytanie i też nie tu miejsce, by takie odpowiedzi proponować. Wydaje mi się jednak istotne, by to pytanie postawić i zdać sobie sprawę $\mathrm{z}$ tego, że dotychczasowe strategie są niewystarczające.

Studenci sami znaleźli jedną z możliwych odpowiedzi w powrocie do wspólnego działania, do koleżeńskiego dialogu:

[W] walce tworzenia - piszą - z pomocą przychodzi istnienie w grupie. [...] [B] udując swoje ja dbamy o to, aby wypełnić wszystkie role w mikrospołeczności, w której żyjemy, a rozwój każdego z nas pośrednio uwarunkowany jest kierunkiem rozwoju wszystkich pozostałych. [...] Chcemy tworzyć indywidualnie, ale zostać zapamiętani razem[8].

Nie sposób przecenić taką wspólnotowość, samokształceniową siłę i solidarność. Co więcej, widać jej efekty, gdyż wiele interesujących inicjatyw w łonie Szkoły pochodzi właśnie od tychże studentów.

[7] Kiedy sam jeszcze byłem studentem fotografii, uczono mnie posługiwania się technologią Flash firmy Adobe, która wówczas wyznaczała standardy prezentacji materiałów multimedialnych w sieci. Dziś już wiadomo, że technologia ta raczej odejdzie do lamusa, a pałeczkę przejmuje html5, przede wszystkim zaś rozwiązania na urządzenia mobilne. Jest to jednak pole, w którym nie ma jeszcze zbyt wielu prostych, dostępnych narzędzi, i trudno powiedzieć, w jakim kierunku się ono rozwinie.

[8] Wstęp, w: Wystawa fotografii. 8,-zł zestaw. IV rok PWSFTViT [katalog wystawy], Łódź 2011, bp. 
Gdyby się jeszcze udało dodać do tego równie intensywną wymianę z pedagogami, którzy nierzadko nie są gotowi uznać studentów za partnerów w dialogu - ale też nazbyt często wciskani są w role belfrów przez samych studentów, roli, w której przeważnie nie czują się dobrze - wtedy stworzylibyśmy układ prawie idealny. Choć nie mam wątpliwości, że cały czas do tego dążymy, obecna sytuacja wyjątkowo sprzyja podobnym refleksjom i przewartościowaniom.

Kiedy prof. Marek Nowicki z okazji piętnastolecia Szkoły ogłosił: „Nie uczymy fotografować!” - ufam, że właśnie coś takiego miał na myśli.

Wystawa nagrodzona łódzkim Plastrem Kultury w kategorii OFF Roku 2013 


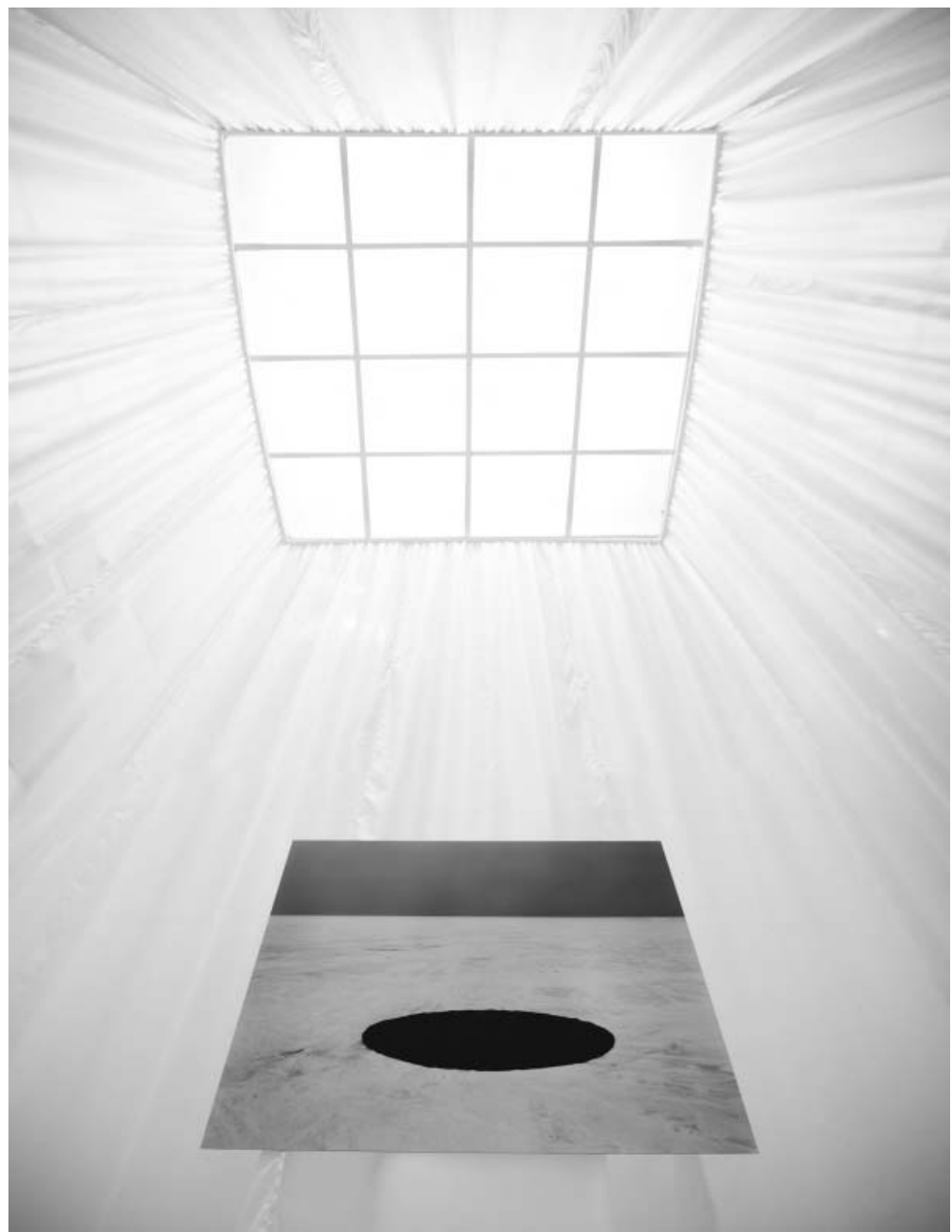

Wystawa \#2olatfotografiipwsftvit - ekspozycja - foto-

grafia z kategorii: \#białe (Anna Orłowska, Soaking in) 


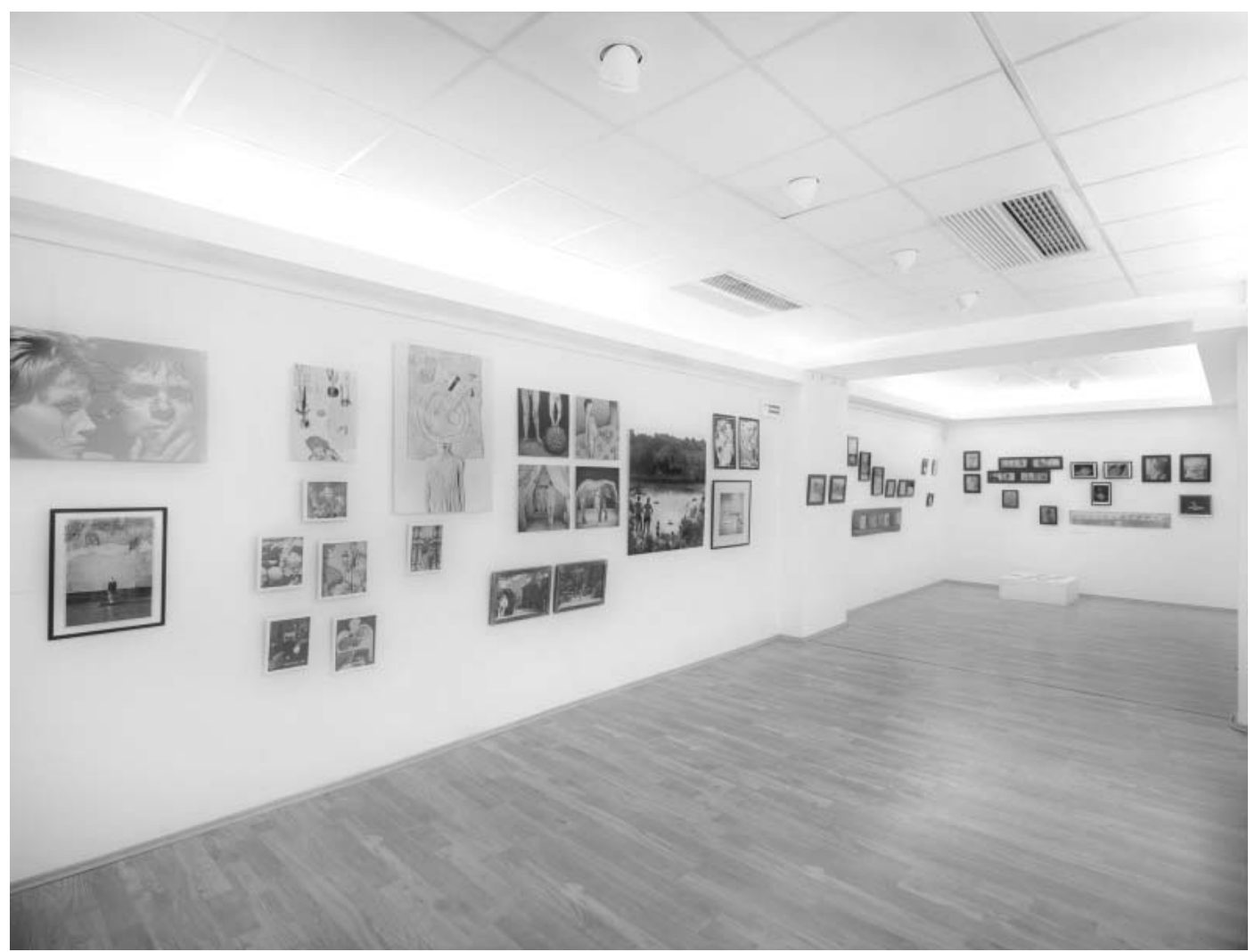




\section{0 \#2OLATFOTOGRAFIIPWSFTVIT}

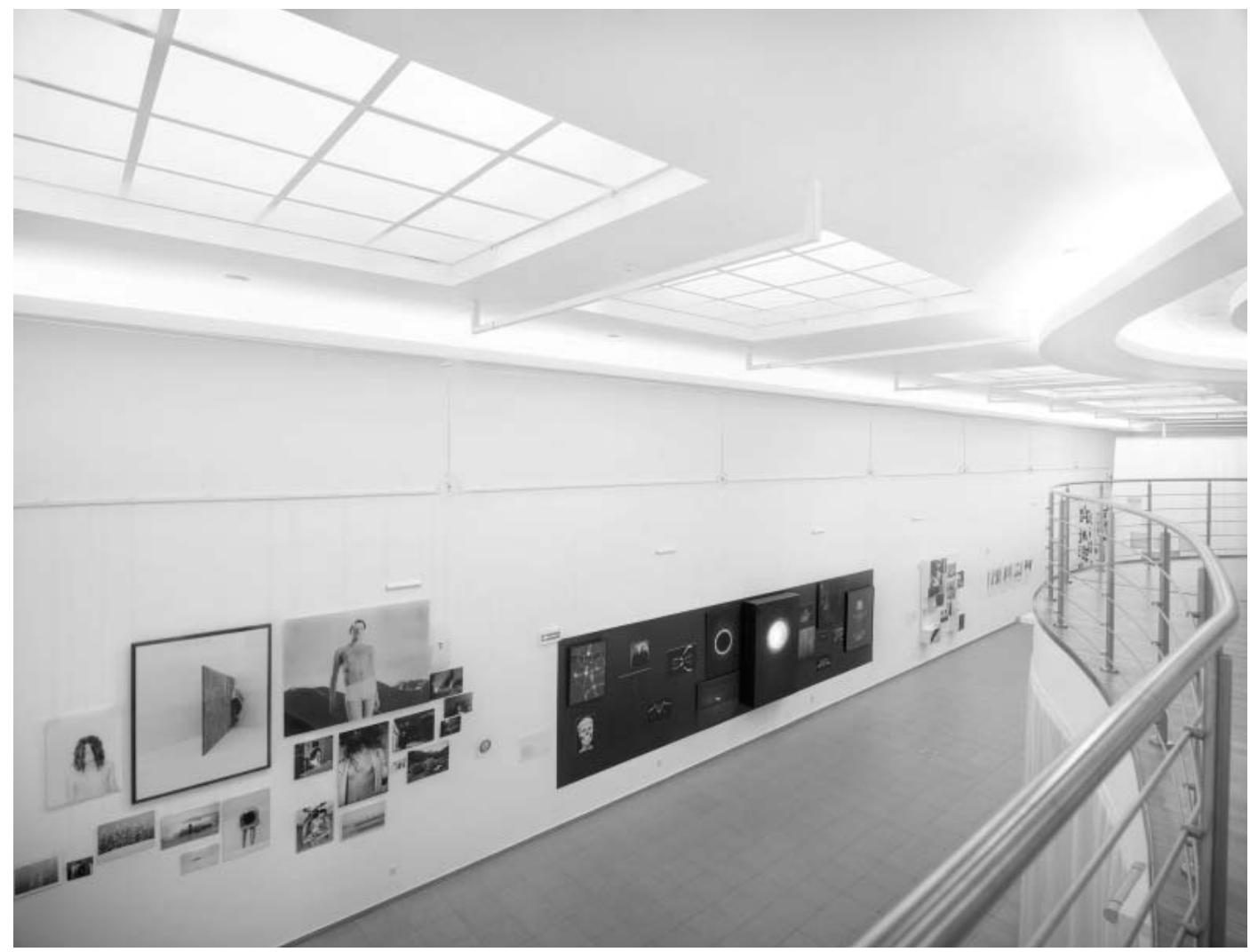

